\title{
A summons to Carthage, December 1943
}

\section{J G Scadding}

I spent most of the years of the second world war serving in the Royal Army Medical Corps. In January 1939, I had been appointed consultant physician to the Brompton Hospital, remaining a member of the staff of the department of medicine at the British (now Royal) Postgraduate Medical School at Hammersmith, which I had joined at its inception in 1935. I was thus embarked on a career as a consultant physician with special interest in respiratory disease. At the outbreak of the war I was posted to the Brompton Hospital in the Emergency Medical Service, but the expected immediate air raids did not occur and, being then a bachelor, I volunteered for the RAMC. I was called up in May 1940 and was posted to Tidworth Military Hospital, where for nine months I was desperately busy as the only medical specialist on Salisbury Plain.

Early in 1941 I was posted to a general hospital that was mobilising to go abroad, and I found that among my fellow officers were a thoracic surgeon and an anaesthetist with special experience of thoracic surgery. We gathered that we were to be established as a surgical chest unit when we arrived at our (then undisclosed) destination. When we arrived in Egypt, however, no one seemed to be expecting us in this capacity; and when after 18 rather frustrating months this unit was established I was not included in it but posted as officer in charge of the medical division of No 19 General Hospital sited at Fayid, about the middle of the Suez Canal.

This was a splendid posting. We had 1800 beds for British and Allied forces and 1000 for prisoners of war and were in the centre of a large area of base units of all three services with transient populations from all over the world; we were far away from the distractions of Cairo, Alexandria, or indeed any urban area, so that we were rarely distracted by unnecessary interference from bigwigs or by what a colleague who was in a similar position in a hospital near Cairo described as "pouring out soothing syrup for the jangled nerves of brigadiers." We acquired extensive, honest to God, medical experience, especially in tropical and infectious diseases; we dealt at one time or another with nearly every important infectious disease then known, including smallpox and plague-the only exceptions were yellow fever and cholera. The hospital was located in the desert, hutted and partly tented, but as it was within a mile or so of the Great Bitter Lake, where there was provision for swimming and even sailing, we were better off than the several hospitals in Egypt that were in unrelieved desert areas. While the war was active in the Middle East we were desperately busy, especially in the summer months, but by the end of 1943 we were beginning to be less hard pressed and had settled down to the routine of keeping the hospital going in what was becoming a quiet backwater.

\section{The summons}

About $530 \mathrm{pm}$ on 15 December, 1943, while engaged in advancing the war effort as president of a medical board, I was informed that orders had come that I was to prepare to move by air in half an hour and that I was to take my equipment. No further information was available, so I packed a few personal necessities and threw in my stethoscope; and duly not one but two cars came, the second presumably in case the first broke down, to drive me the 80 miles or so to Cairo. My status had evidently risen sharply since the morning, when I had had to beg a lift on a truck to go three or four miles down the road to make some purchases at the NAAFI! (Perhaps I should explain that this acronym stands for Navy Army and Air Force" Institutes, and provides among other things shopping facilities for those in the Armed Services.)

I reported to Air Movements in Cairo and was told that a Lockheed Lodestar (the Lockheed equivalent of the DC3) was taking off at $11 \mathrm{pm}$ to take me to Tunis; but the duty officer could give me no idea of why I was being taken there. I had time to go to Shepheard's for dinner before I boarded the plane and was flown through the night, touching down at El Adhem and Castel Benito, to Tunis, arriving about 7 am. I was outside the command to which I belonged, without a movement order, and still unaware of why I had been sent. I located a RAF administrative officer who inquired for me and said that the commander in chief's car was coming to pick me up, but he didn't know what for.

In 10 minutes, a large American car appeared and conveyed me seven miles to Carthage, where, after passing through two peripheral cordons of American sentries and two British guardsmen at the door, I entered a large white house. The first person I met inside was Evan Bedford; he was then consultant physician to the Middle East Forces, and I knew him well, since he was physician to the Middlesex and National Heart Hospitals, and 13 years earlier I had been his house physician. He had arrived the previous evening, and told me that we had been summoned from Egypt at Moran's request, because Churchill, who had arrived from Cairo five days earlier to consult with General Eisenhower on his way home, had developed pneumonia. So I learnt for the first time why I was there.

\section{Dealing with the great man}

Moran, who accompanied Churchill on his wartime travels as his personal physician, has told the story of his illnesses, including this one. ${ }^{1}$ I shall say nothing not revealed in Moran's book about the medical history of this distinguished patient. Churchill had been taken ill soon after arriving at Eisenhower's villa on December 11 after a tiring and interrupted flight from Cairo. When he became febrile, Moran, apparently unaware that there was an RAMC General Hospital in Tunis, which he regarded as a "God-forsaken spot-no nurses, no milk, not even a chemist," summoned up medical and nursing help from Cairo, asking first for nurses and a pathologist. In response to this, two nurses and RJV Pulvertaft, who in civil life was pathologist to the Westminster Hospital, were sent. A radiograph was taken on a portable apparatus by a civilian radiologist summoned from Tunis; it showed evidence of pneumonia, and sulphapyridine, the sulphonamide then most favoured for the treatment of pneumonia, was started. Moran resisted pressure from the Cabinet to send for consultants from London and asked for Bedford, whom he knew to be in the Middle East, and G A H Buttle, as an expert on sulphonamides, to be sent from Cairo. I have no reason to doubt Moran's statement that it was to placate the Cabinet
J G Scadding, emeritus professor of medicine

BMY 1993;307: 1595-6 


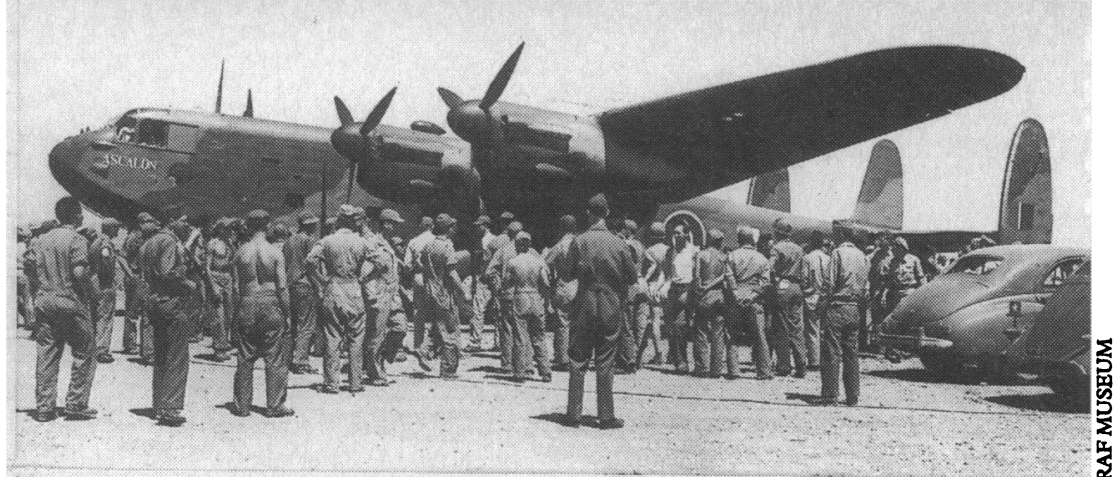

Churchill's easily recognisable personal York aircraft. "I had the privilege of returning to Cairo as the sole passenger, sitting at Churchill's desk in his comfortable chair"

that he had asked "the people at Cairo" to send me also. By the time I arrived, Churchill was recovering. My sole contributions were to sign two of the bulletins and to join the consensus against the idea of trying the new wonder drug, penicillin. At that time, the only available preparation was a yellow injectable solution, of which the usual dose was about 50000 units. I recall commenting that our patient was progressing well on accepted treatment, and that one does not make therapeutic experiments on the prime minister.

There are two respects in which my recollection of events during the five days I was in Carthage differs from Moran's account. The first is on a matter of objective fact, but trivial; in his entry for 16 December, Moran says "Scadding arrived tonight." In fact I arrived early in the morning of that day. The second is subjective, but to my mind more serious. The entry for 20 December states that "Now that the PM is beginning to be convalescent he is very difficult. ... He has been savaging Bedford and Scadding, who know their job and have been helpful . . . when Bedford advised him to rest for a fortnight, Winston suddenly became red in the face with rage," and goes on to recount in dramatic terms the ensuing conversation, and how he (Moran) "was upset by Winston's rough handling of my colleagues." I did not keep a diary of these events, but I am sure that I should not have forgotten the experience of being "savaged" by Churchill. My recollection is that the conversation recorded by Moran did occur, but without the emotional overtones. Moran's account of it seems to me to be unfair to Churchill, representing him as being discourteously overbearing. Like many patients with heavy responsibilities, he demanded to be told the evidence on which we gave this advice, and Bedford and I made the usual replies, in which Moran supported us; but the suggestion that he had to rescue us from Churchill's rage must be, to say the least, exaggerated. In the event, Churchill remained quietly in Eisenhower's villa until 27 December, and then spent 4 or 5 weeks quietly convalescing at Marrakesh.

I am fairly certain that Moran summoned help from Egypt in this episode because he knew who was stationed there and not who was in North Africa. As it turned out, this contributed to security; all those who signed bulletins were stationed in the Middle East, and this suggested that Churchill was ill somewhere in that area, which he was known to have been visiting.

\section{A fitting conclusion}

During our stay in Carthage, Buttle, Pulvertaft, and I lived in great comfort in a delightful villa, which we were told had belonged to a disgraced financier and had been taken over as a guest annex to Eisenhower's villa. After four days it was decided that I was no longer required, even as a sop to the Cabinet. It dawned on someone about this time that Churchill's easily recognisable personal York aircraft parked on Tunis airfield was a security risk and should be sent back to Cairo, so I had the privilege of returning in it by day in one hop as the sole passenger, sitting at Churchill's desk in his comfortable chair; very different from the spartan conditions of my overnight flight from Cairo. I felt that I was getting the VIP treatment, especially as my orders were to report to the Commander in Chief, British Troops in Egypt, in Cairo, and refuse to answer questions from anyone else. Having carried out these orders, I went back to Fayid and continued my humdrum function in charge of the medical division of No 19 General Hospital until I returned home at the end of July 1945 after four years and four months in the Middle East.

My wife's experiences with the popular press when my name appeared on the bulletins were far from happy. We had been married for only six months when I embarked for the Middle East in March 1941. In December 1943 she was living with her sister in a village in Yorkshire and working as welfare officer in a mill which had been turned over to making electric cables for aircraft, employing many women who had been evacuated from large towns. Her letters to me provide a written record of events. On 19 December she wrote that from 330 to $8 \mathrm{pm}$ she had constantly been answering the telephone or seeing reporters who had tracked her down. She had tried to tell them as little as possible, feeling that I disliked publicity as much as she did.

On the following day, when the reports appeared, she was annoyed to find that in several newspapers these included statements supposed to have come from her, but far from the truth, and she was especially distressed by one which alleged that she had said, "This news has made the years of waiting worth while." Anyone who knows my wife will know how unlikely it is that she would say anything so embarrassing, and how outraged she was that these words had been put into her mouth. She found to her relief that this had appeared only in the northern editions.

She telephoned the editors of the two papers which had printed the worst fabrications to protest, but of course without any satisfaction.

In 1946, when our first child was born, one newspaper retained in its files the record of my presence in Carthage and thought the event interesting enough to warrant a paragraph with the headline "Daughter for Churchill's doctor." Neither my wife nor I liked this very much. I had no wish to be identified as the doctor of any one person, however distinguished; and we are both relieved that I have never again hit the headlines of the popular press.

1 Moran C. Winston Churchill: the struggle for survival 1940/1965. London: Constable, 1966.

Christmas competition: How targeted are your briefs?
You may be speaking jargon without even BMJ, BMA House, Tavistock Square, London
knowing it-so try your hand at this year's WC1H 9JR, by 15 January. The best entries
competition. Ghodes and Rang's exposé of will be published (unedited) in February, and
NHS-speak (p 1626) concludes with a paragraph the very best will receive a copy of How to
showing the language in action; can you equal or Write a Paper, the BMJ Publishing Group's new
top it, including the latest buzz words and guide to successful submissions. The editor's
circumlocutions? Entries should arrive at the decision is final.

